\title{
Censure threatened against Manitoba medical school
}

Published at www.cmaj.ca on May 21

$\mathrm{T}$ he University of Manitoba in Winnipeg and the province's largest health authority are on a collision course with Canadian university professors over the firing of an outspoken family physician.

The Canadian Association of University Teachers (CAUT) has threatened to censure both the university and the Winnipeg Regional Health Authority (WRHA) unless they reinstate Dr. Larry Reynolds, formerly the head of family medicine at the university and a tenured full professor in its medical faculty.

If the teachers' association follows through, it will be the first time in more than three decades that a Canadian postsecondary institution has been censured for an attack on academic freedom. The last Canadian university to be censured was Memorial University of Newfoundland, in 1979.

The heath authority was named in the CAUT's proceedings because all medical school positions in Manitoba are joint appointments with the health authority. Although there is no specific penalty attached, censure would result in the teachers' association actively discouraging academics and medical professionals from accepting positions at the University of Manitoba.

"It is quite unusual for something like this to get to this point," says CAUT executive director James Turk. "Censure is a very serious matter. We are normally able to resolve most of the complaints we receive long before we get to the censure stage. This is an exception to that."

This dispute began in 2008, when Manitoba's largest university and only medical school chose not to renew Reynolds' term as head of family medicine. Subsequently, the school also fired him from his position as a tenured full professor.

When the dispute was first publicized, senior management at the health authority broke its normal policy of not commenting on personnel issues and said Reynolds was fired for poor job performance; specifically, he was a poor leader and did not work well with others.

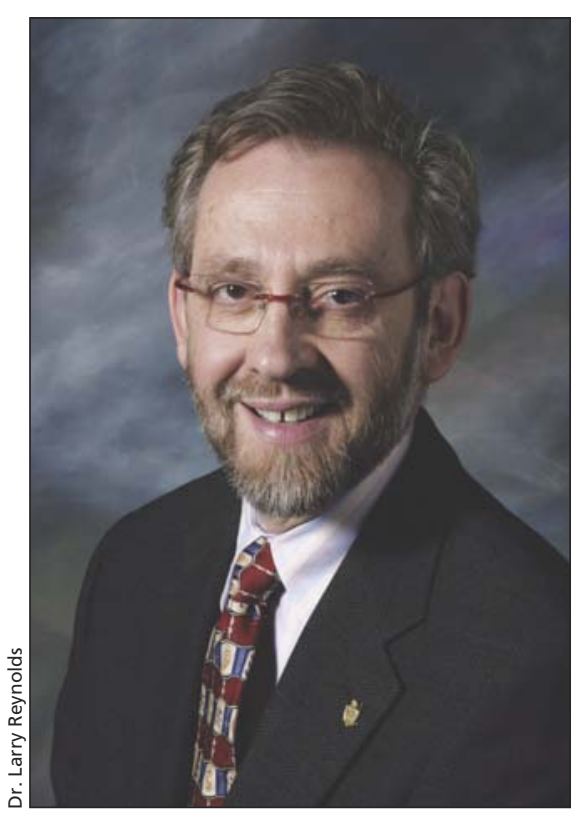

Dr. Larry Reynolds' dismissal from the medical faculty of the University of Manitoba is viewed by some academics as an attack on academic freedom.

The teachers' association became involved after two medical academics from outside Manitoba lodged complaints that Reynolds' academic freedom was being attacked. At first, it did not appear the association could get involved, Turk notes, because Reynolds had only at that time been relieved of his duties as head of a department at the medical school. He continued to teach at the university. The termination of his position as department head would not have been considered an attack on academic freedom.

However, shortly after the teachers' association began looking at the Reynolds' case, the university also fired him from his tenured position at the faculty of medicine. Turk says there was immediate concern that this constituted an attack on academic freedom, and an investigation committee was struck to examine the facts behind the dismissal.

The investigation revealed that Reynolds was an outspoken advocate for family medicine. In one highly publicized incident, Reynolds lobbied for guaranteed hospital privileges for family physicians to handle obstetrical procedures, including births. Another time, he was quoted in local media opposing the closure of the obstetrics department at a Winnipeg hospital.

The investigation revealed that these conflicts ultimately made him extremely unpopular with the senior levels of the medical school, Turk says. However, among his own colleagues, it appears Reynolds was popular.

Perhaps sensing that some in the medical school would fight the renewal of his term as department head, Reynolds hired a third party to conduct a survey of the family services department. More than $80 \%$ of respondents indicated they would like to see him remain as the head of family medicine, notes Turk.

Reynolds was recruited to the university in 2002 and was considered at the time a prize catch. After he was fired as head of family medicine, he attempted to apply for other teaching positions but was told he was ineligible to apply for any position at the university.

Reynolds, who continues to work in a Winnipeg hospital, declined to comment on the CAUT proceedings. Both the university and health authority also declined to comment directly on the case.

In an email statement, the health authority notes that CAUT is an organization charged with protecting academic freedom at universities, and the health authority is not an educational facility. A spokeswoman adds that because the authority is currently "in negotiations with Dr. Reynolds and his lawyer, no one from the WRHA will be speaking outside that process." 
The university, meanwhile, would not entertain any questions, but did release a statement disputing the findings of the teachers' association investigation. "The University does not believe that the story as related by CAUT represents a fair and accurate account of the details in this case and believes that bias was present from the beginning of the CAUT inquiry process," spokesman John Danakas states in an email. "Specific concerns with the independence and fairness of the investigation include a failure to obtain evidence and a failure to fairly consider evidence."

Turk says those allegations are concerning given that, while leveling a number of allegations against
Reynolds, the medical school was unable to produce a single page of evidence to support them. At one point, the school claimed Reynolds voluntarily resigned, a charge not supported by the available evidence.

"There is no doubt that he did raise the ire of some of the senior administration at the university," Turk says. "We've been going through this for the last two years. If they had any evidence to back up these complaints, all they had to do was forward the information to us. They haven't been able to give us anything."

Typically, after an investigation is completed, the results are presented to the university involved and negotiations are undertaken to resolve the dis- pute. If a resolution is not forthcoming, the teachers' association board can vote to censure an institution. However, after that vote, a six-month window is left to reach some sort of agreement, Turk adds.

Since the CAUT board voted unanimously in April to censure the University of Manitoba, there has been no meaningful contact with the school or the health authority. This, despite numerous attempts to open a dialogue with both institutions to avoid censure, Turk adds.

"We're still hopeful that we can use the six months to get this resolved." Dan Lett, Winnipeg, Man.

DOI:10.1503/cmaj.109-3266 